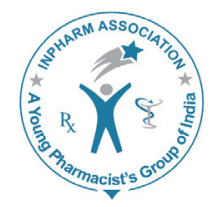

\title{
Essential Oil from Origanum vulgare Linnaeus: An Alternative against Microorganisms responsible for Bad Perspiration Odour
}

\author{
Suzuki Érika Y', Soldati Pedro P1', Chaves Maria das Graças A. M², Raposo \\ Nádia R. $B^{1^{*}}$ \\ ${ }^{1}$ NUPICS, Faculdade de Farmácia, Universidade Federal de Juiz de Fora, Rua José Lourenço Kelmer, s/n, \\ 36036-900 Juiz de Fora-MG, Brasil. \\ ${ }^{2}$ NUPITE, Faculdade de Odontologia, Universidade Federal de Juiz de Fora, Rua José Lourenço Kelmer, \\ s/n, 36036-900 Juiz de Fora-MG, Brasil.
}

\begin{abstract}
Objective: The aim of this study was to evaluate the antimicrobial activity of the essential oil from Origanum vulgare Linnaeus against the main bacteria responsible for bad perspiration odor (Corynebacterium xerosis IAL 105, Micrococcus luteus ATCC 7468, Proteus vulgaris ATCC 13315 and Staphylococcus epidermidis ATCC 12228) and to develop the formulation of a deodorant containing the essential oil as antimicrobial agent. Method: The antimicrobial activity was evaluated by means of the turbidimetric method, by using the microdilution assay. The chemical profile of the essential oil was evaluated by high-resolution gas chromatography (HR-GC). Results: seventeen constituents were identified, being that $\mathrm{y}$-terpinene $(30.5 \%)$ and carvacrol $(15.7 \%)$ were the major components found. The essential oil exhibited antimicrobial activity against all microorganisms tested and the minimum inhibitory concentration (MIC) values ranged from 0.7 to $2.8 \mathrm{mg} / \mathrm{mL}$. Electron microscopies confirmed the morphological alteration in the structure of the bacteria treated with the essential oil as compared to control. The formulation of the deodorant demonstrated bactericidal activity and it was able to cause damage in the morphological structure of the treated bacteria. Conclusion: The essential oil from $\mathrm{O}$. vulgare can be used as a potential natural antimicrobial agent to be applied in personal care products.
\end{abstract}

Key words: Deodorants, Origanum vulgare, Personal care products, Antimicrobial action.

\begin{tabular}{|l|l|}
\hline \multicolumn{2}{|c|}{ Access this article online } \\
\hline \multicolumn{3}{|c|}{ Journal Sponsor } & $\begin{array}{l}\text { Website: } \\
\text { www.jyoungpharm.org }\end{array}$ \\
\cline { 2 - 2 } & \\
\cline { 2 - 2 } & Dol: \\
& $10.5530 /$ jyp.2015.1.4 \\
& \\
\hline
\end{tabular}

\section{INTRODUCTION}

Personal care products (PCPs) (e.g. deodorant, toothpaste, soap, shampoo) are constantly used nowadays. Nevertheless, synthetic compounds present in PCPs can affect people's health and the environment. ${ }^{1,2}$

\section{*Address for correspondence:}

Dr. Raposo Nádia R. B, Universidade Federal de Juiz de Fora, Faculdade de Farmácia Núcleo de Pesquisa e Inovação em Ciências da Saúde, Campus Universitário - Bairro Martelos, CEP 36036-900-Juiz de Fora-MG, Brazil.E-mail: nadiafox@gmail.com 
Triclosan, a common ingredient used in PCPs, has become the most widely used antibacterial agent in the United States. This biocide is among the most commonly detected PCPs in surface waters and biosolids. Therefore, it has been suggested that exposure to Triclosan in the environment may select tolerant bacterial strains and exhibit increased resistance to antibiotics. ${ }^{3,4}$

The continuous emergence of bacterial strains resistant to conventional treatments has become a major problem in recent years. ${ }^{5}$ Furthermore, triclosan is sufficiently persistent in the environment, thus it readily bioaccumulates in aquatic organisms, creating a chronic exposure for those organisms. ${ }^{3,4,6-8}$ Due to this fact, there is a growing consumer demand for natural ingredients, which are perceived as being healthier and ecological. ${ }^{9}$ The use of natural products of plant origin demonstrates a low possibility of microbial resistance development because of their complex chemical mixtures. ${ }^{10,11}$ The natural ingredients have been the favorites in the cosmetic and personal care marketing departments, ensuring almost immediate consumer attention, along with the willingness to pay premium prices for such products. According to a Natural Marketing Institute survey, $59 \%$ of women indicate that $100 \%$ natural ingredients are very or somewhat important for them when purchasing PCPs. ${ }^{12}$

Essential oils and their components are increasingly gaining interest because of their relatively safe status, their wide acceptance by consumers, and their exploitation for potential multi-purpose functional use. They have been used in food preservation, aromatherapy, pharmaceuticals, fragrance industries, alternative medicine and natural therapies. ${ }^{13}$

Essential oils refer to the subtle, aromatic and volatile liquids isolated from different parts of plants through distillation. Such materials, which are used for their beneficial effect on the skin, are cost-effective and in some instances may enhance the Dermo-cosmetic properties of the final product. Certain essential oils are known to possess other interesting properties, such as antibacterial or antifungal. Such properties allow their usage alone or in combination with chemical preservatives for the preservation of cosmetic products. ${ }^{5,14,15}$

In terms of Ecotoxicology, in contrast to some synthetic products, the constituents of essential oils are biodegradable and most of them have little persistence in the environment. ${ }^{16}$

Oregano (Origanum vulgare Linnaeus) is an aromatic herb belonging to the Lamiaceae family, and distributed in Eurasia, North Africa and North America. ${ }^{17}$ This wellknown aromatic herb is considered one of the most widely used spices in the world and is officially accepted in many countries for its medicinal value. ${ }^{18}$ Due to their variety in regards to chemistry and aroma, different Origanum species are frequently used as raw material in pharmaceutical and cosmetic industry in order to get spicy fragrances. ${ }^{19}$ Oregano has also been found to exhibit ant thrombin, ant hyperglycemia, antiflammatory, hepatoprotective as well as antimicrobial effects. ${ }^{20-22}$

Deodorants belong to the PCPs group and are used to mask and reduce body odor. They usually contain antimicrobials such as triclosan, which decrease the number of bacteria and hence the unpleasant smell of the microbial secretion compounds. ${ }^{23}$ The German market of deodorants rose to $€ 705$ million in 2010 and it was the PCPs with the biggest increase compared to the two previous years. It is estimated that $65.2 \%$ of adult men and $73.3 \%$ of adult women use deodorants at least once a day. ${ }^{23,24}$ Currently, Brazil is the third worldwide market on cosmetics, perfumes and hygienic products and it occupies the first position in the world ranking of deodorants and fragrances. ${ }^{25}$

In this context, the aim of the present study was to evaluate the antimicrobial activity of the essential oil from $O$. vulgare L. against the main bacteria responsible for bad perspiration odor and to develop a deodorant formulation containing said essential oil as an antimicrobial agent.

\section{MATERIAL AND METHODS}

\section{Essential oil}

The essential oil from Origanum vulgare leaves (lot 660411) was commercially obtained from Lazlo Aromatologia Ltda.

\section{Gas chromatography}

In order to qualitatively and quantitatively characterize the main chemical constituents of this essential oil, an aliquot was subjected to analysis by high-resolution gas chromatography (HR-GC) (HP 5890) equipped with flame ionization detector. A BP-1 (SGE) $30 \mathrm{~m}$ x $0.25 \mathrm{~mm}$ column was used, with a temperature gradient of $60^{\circ} \mathrm{C} / 1 \mathrm{~min}$, $3^{\circ} \mathrm{C} / \mathrm{min}$ to $220^{\circ} \mathrm{C}$; injector (split of $1 / 50$ ) at $220^{\circ} \mathrm{C}$ and detector at $220^{\circ} \mathrm{C}$. The carrier gas used was hydrogen $(2$ $\mathrm{mL} / \mathrm{min}$ ) and the injection volume was of $1 \mu \mathrm{L}$. Samples were diluted to $0.5 \%$ in chloroform. Identification of essential oil components was based on the retention times of sample components and a mixture of $n$-alkanes from $\mathrm{C}_{10}-\mathrm{C}_{18}$ and the calculated Kovats Index was compared with the available literature. ${ }^{26}$ 
Antimicrobial activity

Microorganisms

Micrococcus luteus (ATCC 7468), Proteus vulgaris (ATCC 13315) and Staphylococcus epidermidis (ATCC 12228) were obtained from the American Type Culture Collection. Corynebacterium xerosis (IAL105) was obtained from Adolfo Lutz Institute Culture Collection.

\section{Antimicrobialscreeningandminimuminhibitoryconcentration} (MIC)

The inhibition of microorganism growth was determined by means of turbidimetric method by using a micro dilution assay in a sterile 96-well microplate (Sarstedt, Germany). ${ }^{27}$ Each well contained $100 \mu \mathrm{L}$ of the essential oil $(0.17-2.8 \mathrm{mg} / \mathrm{mL})$ and $100 \mu \mathrm{L}$ of Brain heart Infusion (BHI) for C. xerosis or Mueller Hinton Broth (MHB) for the other bacteria representing, approximately, $4 \times 10^{3}$ colony-forming units $(\mathrm{CFU}) / \mathrm{mL}$. The micro plates were incubated at $35^{\circ} \mathrm{C}$ for 24 hours. Next, $30 \mu \mathrm{L}$ of aqueous solution of $0.01 \mathrm{mg} / \mathrm{mL}$ resazurin was added to each well and the micro plate was reinsulated for 4 hours. The MIC values were determined by change in color, with MIC indicated by the highest dilution remaining blue. In addition, chloramphenicol $(0,025-250 \mu \mathrm{g} / \mathrm{mL})$, triclosan $(0.24-1,000 \mu \mathrm{g} / \mathrm{mL})$ and neomycin $(0.0125-125 \mu \mathrm{g} /$ $\mathrm{mL})$ were used as reference drugs. Tests were carried out in triplicate.

\section{Minimum bactericidal concentration (MBC)}

In order to determine the minimum bactericidal concentration value, wells showing absence of growth in the MIC assay were identified and $20 \mu \mathrm{L}$ of each well were transferred to tubes with Tryptone Soy Broth (TSB). The tubes were incubated at $35^{\circ} \mathrm{C}$ for $24 \mathrm{~h}$. The $\mathrm{MBC}$ value was regarded as the lowest concentration of the essential oil where no visible growth was observed.

\section{Scanning electron microscopy analysis}

The scanning electron microscopy (SEM) was used to investigate morphological changes in the strains of interest submitted to the treatment with the essential oil, chloramphenicol, triclosan and neomycin. ${ }^{28}$ The bacteria cells were incubated for 24 hours in MHB (S. epidermidis, $P$. vulgaris, $M$. luteus $)$ or $\mathrm{BHI}($ C. xerosis $)$ at $35^{\circ} \mathrm{C}$. The suspension was treated with the essential oil or the reference drugs (chloramphenicol, triclosan and neomycin) at $\mathrm{MBC}$ value, and then the samples were reincubated at $35^{\circ} \mathrm{C}$ for 24 hours. After incubation, cells were harvested by centrifugation for 10 minutes at 5,000 $\mathrm{x} g$ and transferred onto slides. The cells were fixed with $2.5 \%$ glutaraldehyde for 12 hours. After that, the slides were washed with $0.1 \mathrm{M}$ phosphate buffer solution ( $\mathrm{pH}$ 7.4), dehydrated with increasing concentrations of ethanol (50 to 100\%) with an interval of 20 minutes between each exchange, and dried at room temperature. The slides were mounted onto stubs using double-sided carbon tape and then metallized in Balzers Union FL - 9496 (Balzers, Germany) with 2 nm of gold for 2 minutes. Subsequently, they were analyzed in the scanning electron microscope JSM 5310 (Jeol, Japan) in high vacuum in secondary electron mode.

\section{PreparationofdeodorantcontainingessentialoilfromO.vulgare}

Two grams of $O$. vulgare oil was dissolved in $60 \mathrm{~mL}$ of grain alcohol. Then, $1 \mathrm{~mL}$ of propylene glycol, $1 \mathrm{~mL}$ of glycerine and $4 \mathrm{~mL}$ of $50 \%$ aluminum chloride hydroxide solution were added, with subsequent homogenization. Under stirring, deionized water was added to complete the volume to $100 \mathrm{~mL}$.

\section{In vitro antibacterial activity of deodorant}

Bacteria were cultivated on TSA plates and incubated at $35^{\circ} \mathrm{C}$ for 24 hours. Then, the plates were sprayed with the deodorant containing essential oil from $O$. vulgare. Each plate was divided into three parts and each part has been sprayed once. This amount was sufficient to ensure the entire area of the plate that was in contact with the formulation. All procedures were performed by the same analyst. The deodorant spray container and the force used to spray the plate were the same. The volume of the preparation that has been sprayed was approximately 80 $\mu \mathrm{L}$. After incubation at $35^{\circ} \mathrm{C}$ for 24 hours, the colonies were inoculated into tubes with TSB (BHI for C. xerosis) to determine cell viability. The absence of turbidity of the culture medium indicated bactericidal activity of the formulation. In parallel, it was evaluated the bactericidal activity of essential oil at $2 \%$. Tests were carried out in triplicate.

In addition, the colonies of different areas of TSA treated with the deodorant were transferred onto slides 24 hours after the application of the formulation. The cells were fixed with $2.5 \%$ glutaraldehyde for 12 hours. The subsequent procedures were performed following procedures previously described in scanning electron microscopy analysis.

\section{RESULTS}

\section{Chemical composition of the essential oil}

Seventeen constituents were identified by HR-GC, accounting for $91.6 \%$ of all components in the essential oil. Other not-listed components are present in amounts of less than $0.1 \%$. Results showed that $\gamma$-terpinene (30.5\%) 


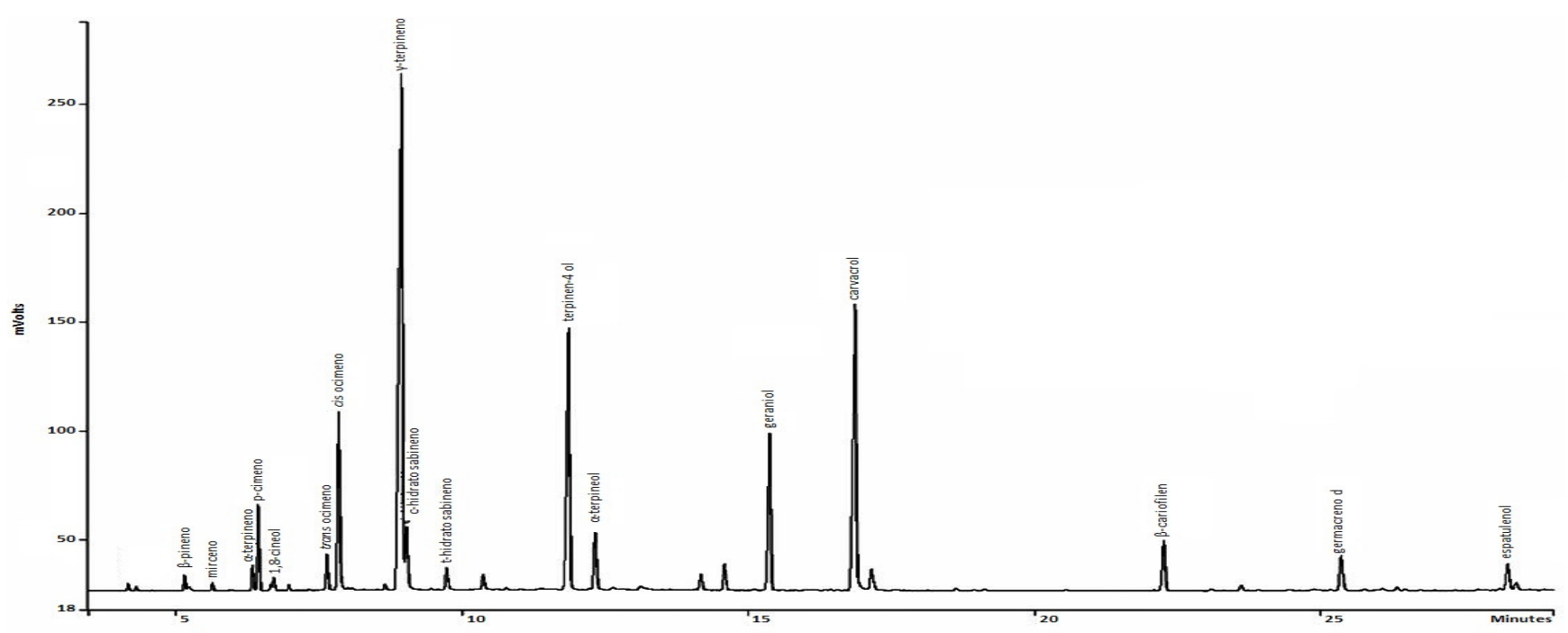

Figure 1: Chromatographic profile of the essential oil from O. vulgare peaks lower than $0.1 \%$ were not documented.

was the compound in highest percentage in the essential oil, followed by carvacrol (15.7\%) and terpinen-4-ol (13.0\%) (Figure 1 and Table 1).

\section{Antimicrobial activity}

\section{Minimal Inhibitory Concentration}

According to the results given in Table 2, the essential oil of $O$. vulgare exhibited the antimicrobial activity against all tested bacteria and demonstrated the bactericidal effect against three of the four tested microorganisms. The MIC values of the essential oil ranged from $0.7 \mathrm{mg} / \mathrm{mL}$ to 2.8 $\mathrm{mg} / \mathrm{mL}$.

\section{Scanning electron microscopy analysis}

SEM observations confirmed the physical damage and considerable morphological alteration to the tested bacteria treated with the oregano oil or reference drugs (chloramphenicol, triclosan and neomycin). Cells treated with essential oil and reference drugs underwent considerable morphological changes when compared to the control group (Figures $2-5$ ). Control cells shoed a regular surface. Exposure of the antimicrobial agents to the bacteria revealed deformed and destroyed cells with probable depletion of their content. In fact, it seems that such compounds are able to alter the cell membrane of the studied bacteria.

\section{in vitro antibacterial activity of deodorant}

The deodorant containing essential oil from $O$. vulgare showed bactericidal activity against all tested bacteria as well as the essential oil at $2 \%$. The electron micrographs of both untreated and deodorant treated cells are presented in Figure 6. Detrimental effects on the morphology of the cell membranes were shown when strains were treated with the deodorant. Incomplete and deformed shape of cell walls was observed. More deformation was noticed in treated P. vulgaris, showing rupture and lysis of the membranes.

\section{DISCUSSION}

In the present work, $\gamma$-terpinene $(30.5 \%)$ was present in higher percentage, followed by carvacrol $(15.7 \%)$, terpinen4-ol (13.0\%), geraniol (7.1\%) and cis-ocimene (7.0\%). Those compounds account for $73.3 \%$ of the total composition of the oil and may be responsible for the biological activity.

The essential oil of O. vulgare is widely known to

\begin{tabular}{|c|c|c|}
\hline Compound & $\%$ & $\begin{array}{l}\text { Kovat's index } \\
\text { calculated }\end{array}$ \\
\hline$\beta$-pinene & 0.4 & 973 \\
\hline Myrcene & 0.2 & 986 \\
\hline a-terpinene & 0.8 & 1017 \\
\hline p-cymene & 2.5 & 1024 \\
\hline 1,8-cineol & 0.5 & 1031 \\
\hline Trans-ocimene & 1.3 & 1049 \\
\hline Cis-ocimene & 7.0 & 1056 \\
\hline $\mathrm{Y}$-terpinene & 30.5 & 1081 \\
\hline Cis-sabinene hydrate & 2.8 & 1085 \\
\hline Trans-sabinene hydrate & 1.0 & 1101 \\
\hline terpinen-4-ol & 13.0 & 1158 \\
\hline a-terpineol & 2.9 & 1170 \\
\hline Geraniol & 7.1 & 1223 \\
\hline Carvacrol & 15.7 & 1241 \\
\hline$\beta$-caryophyllene & 2.5 & 1297 \\
\hline Germacrene D & 1.9 & 1471 \\
\hline Spathulenol & 1.5 & 1545 \\
\hline Total & 91.6 & \\
\hline
\end{tabular}




\begin{tabular}{|c|c|c|c|c|c|c|c|c|}
\hline \multirow[t]{2}{*}{ Microorganisms } & \multicolumn{2}{|c|}{$\begin{array}{l}\text { Essential oil of } 0 . \\
\text { vulgare }\end{array}$} & \multicolumn{2}{|c|}{ Chloramphenicol } & \multicolumn{2}{|c|}{ Neomycin } & \multicolumn{2}{|c|}{ Triclosan } \\
\hline & MICa $^{a}$ & $\mathrm{MBC}^{\mathrm{a}}$ & $\mathbf{M I C}^{\mathbf{b}}$ & $\mathbf{M I C}^{\mathbf{b}}$ & $\mathrm{MBC}^{\mathrm{b}}$ & $\mathrm{MBC}^{\mathrm{b}}$ & MIC $^{b}$ & $\mathrm{MBC}^{\mathrm{b}}$ \\
\hline $\begin{array}{l}\text { S. epidermidis } \\
\text { ATCC } 12228\end{array}$ & 2.8 & - & 2.5 & 0.48 & 3.9 & 25 & 1.25 & 1.25 \\
\hline $\begin{array}{l}\text { P. vulgaris ATCC } \\
13315\end{array}$ & 0.7 & 1.4 & 2.5 & 0.97 & 0.97 & 25 & 12.5 & 12.5 \\
\hline $\begin{array}{l}\text { M. luteus ATCC } \\
7468\end{array}$ & 0.7 & 2.8 & 2.5 & 1.95 & 62.5 & 25 & 12.5 & 125 \\
\hline C. xerosis IAL 105 & 0.7 & 1.4 & 25 & 7.81 & 62.5 & 250 & 1.25 & 1.25 \\
\hline
\end{tabular}

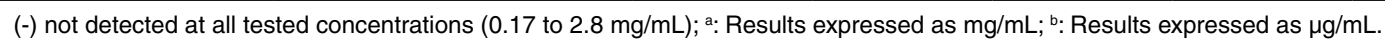
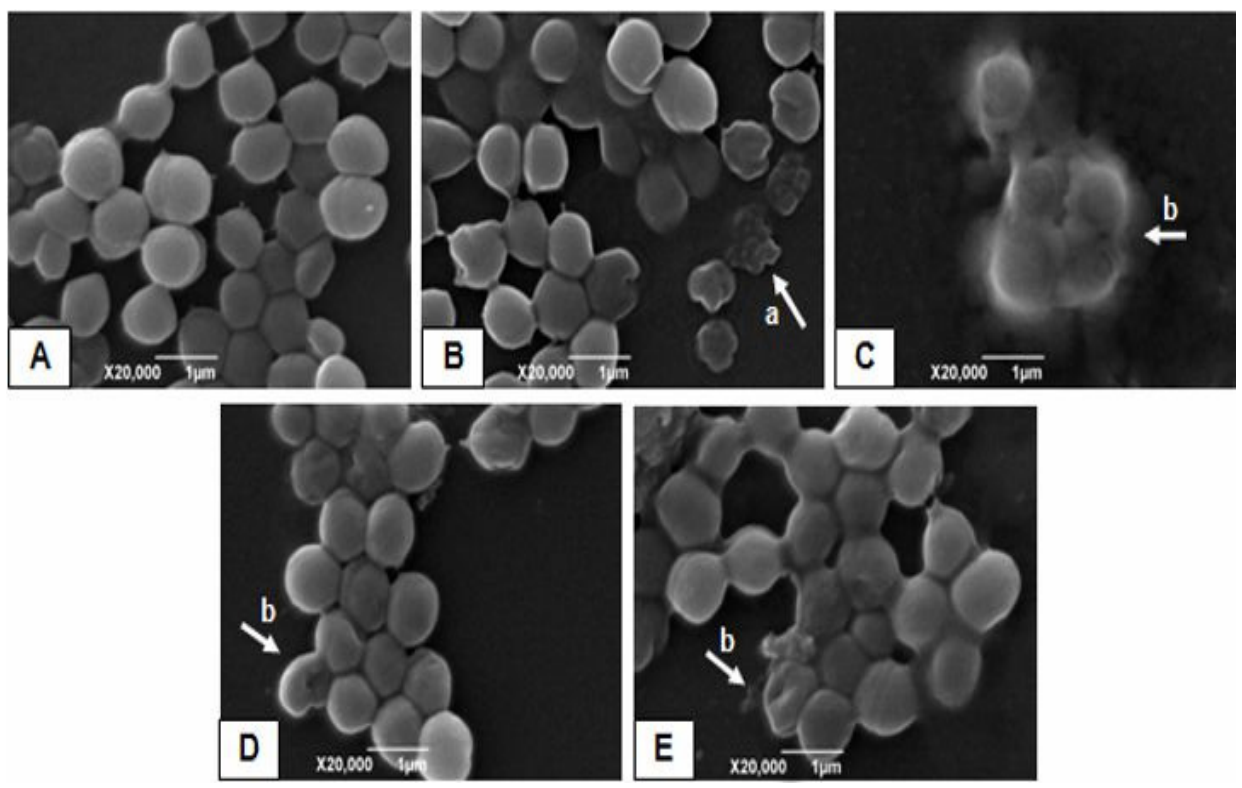

Figure 2: SEM images of S. epidermidis ATCC 12228. A: untreated bacterial cells, B: treatment with chloramphenicol, C: treatment with neomycin, D treatment with triclosan D: treatment with essential oil of O. vulgare. "a": shows destroyed cells, "b": indicates aggregated/deformed cells
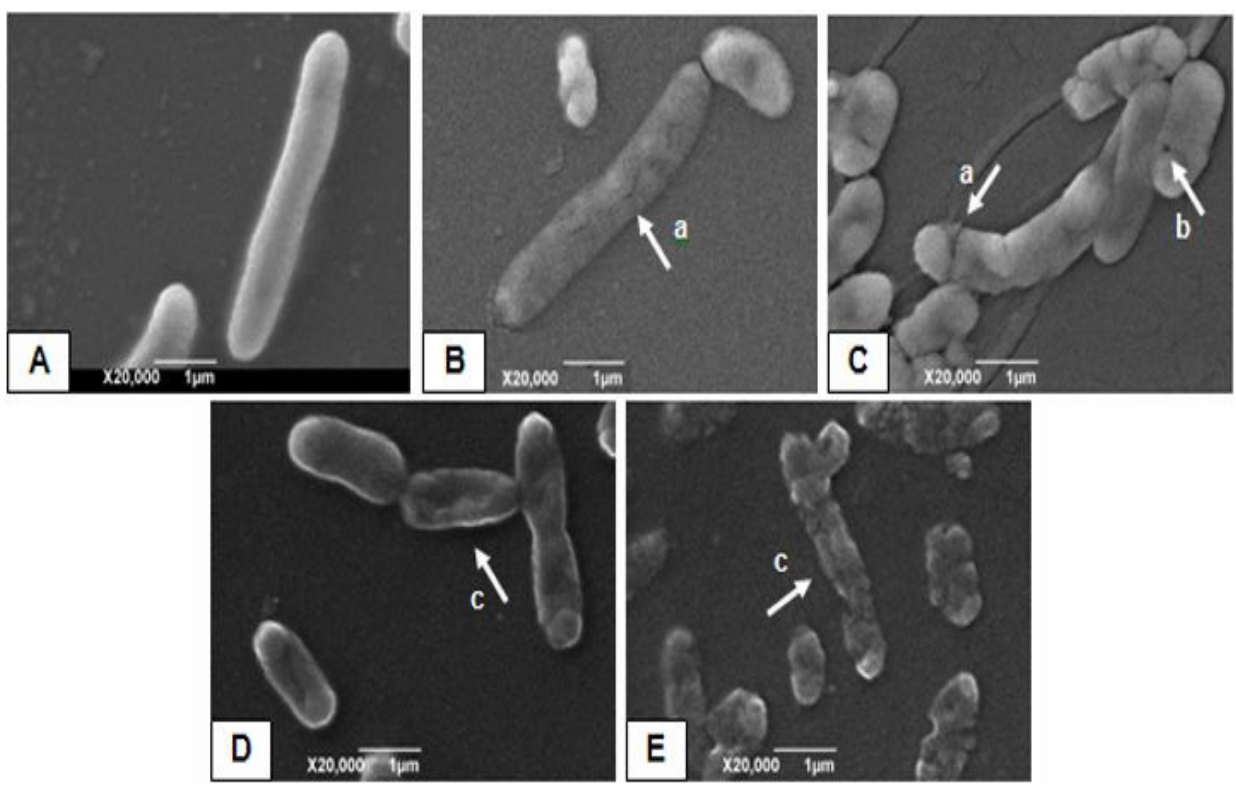

Figure 3: SEM images of $P$. vulgaris ATCC 13315. A: untreated bacterial cells, B: treatment with chloramphenicol, C: treatment with neomycin, D: treatment with triclosan D: treatment with essential oil of O. vulgare. "a": cleft formation, "b": pore formation, "c": destroyed/deformed cells. 

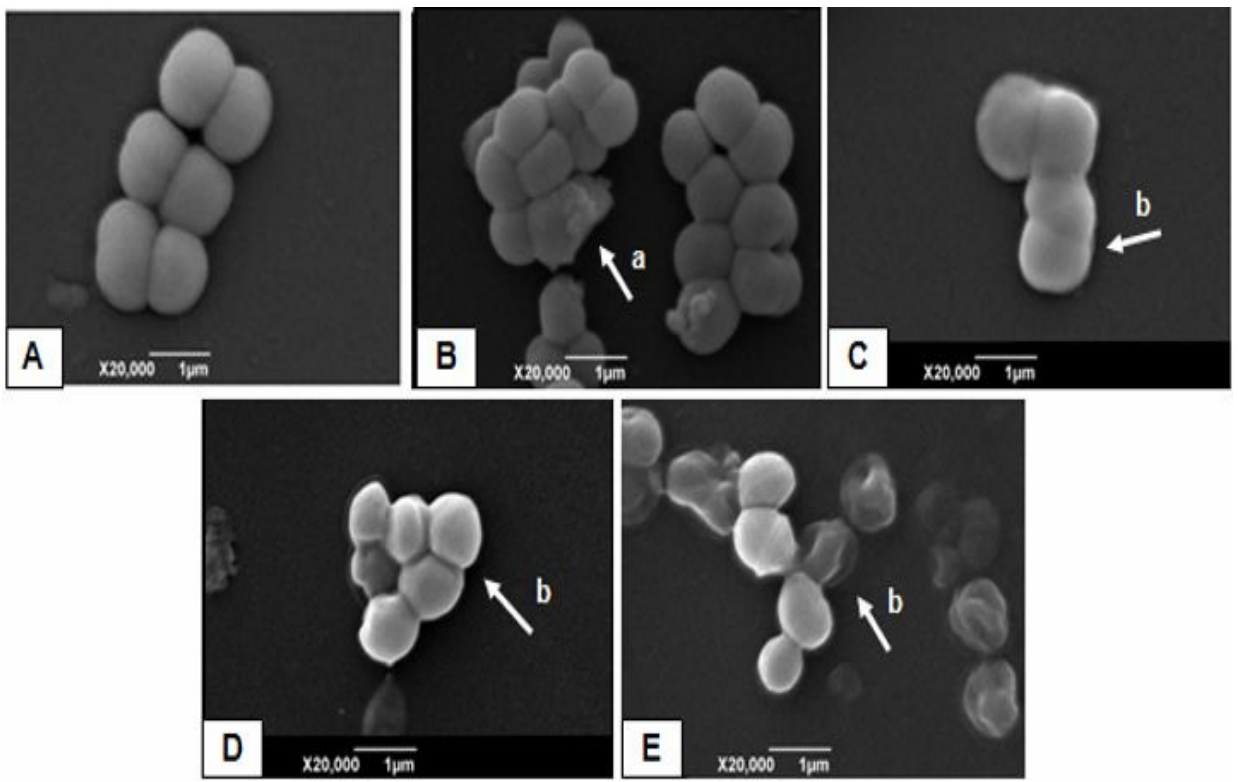

Figure 4: SEM images of M. luteus ATCC 7468. A: untreated bacterial cells, B: treatment with triclosan, C: treatment with neomycin, D: treatment with essential oil of O. vulgare. "a": shows wrinkled abnormalities, "b": indicates aggregated/deformed cells.
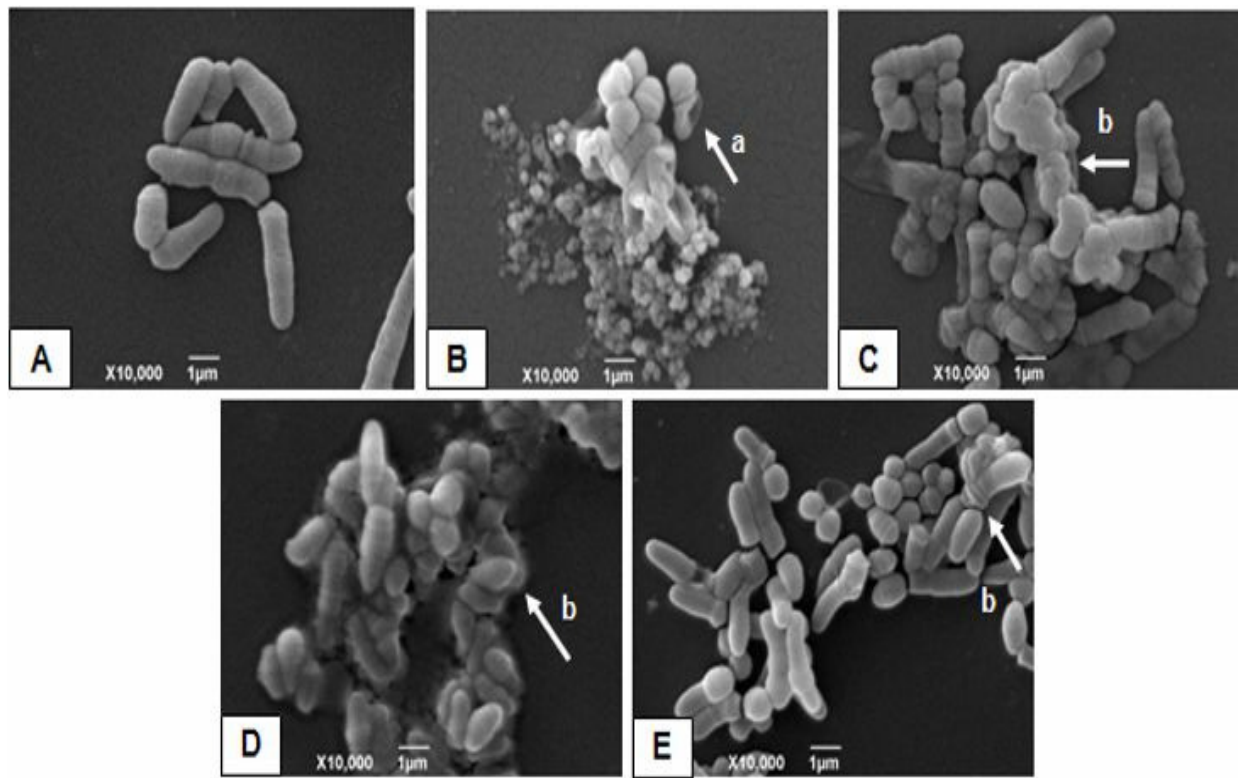

Figure 5: SEM images of $C$. xerosis IAL 105. A: untreated bacterial cells, B: treatment with triclosan, C: treatment with neomycin, D: treatment with essential oil of O. vulgare. "a": indicates disruption and lysis of membrane integrity, "b": indicates aggregated/deformed cells.

obtain antimicrobial properties against various species of microorganisms, especially pathogenic and food spoilage. ${ }^{29,30}$ Nevertheless, our study confirmed that this oil can also be a natural active as an alternative for usage in personal care products such as deodorants, due to its antimicrobial activity against the main bacteria responsible for bad perspiration odor. Its antibacterial properties are often associated with the phenolic compounds caracole and thymol and their precursors $\gamma$-terpinene and $p$-cymene. Those compounds frequently appear as the major components of this oil. ${ }^{31-33}$ In the current study, the presence of all mentioned Journal of Young Pharmacists Vol 7 • Issue 1 • Jan-Mar 2015 compounds, except thymol, was identified. However, this constituent could be included in the percentage observed in amounts of less than $0.1 \%$ which were not listed in this study. ${ }^{18}$ the proportion of thymol and $\gamma$-terpinene in the essential oil of O. vulgare can differ during the flowering and non-flowering stages of the plant. The increase of one of these constituents is accompanied by a decrease of the other and vice-versa. The author also suggests that this factor does not interfere in the content of the other two main compounds: carvacrol and $p$-cymene. ${ }^{34}$ reported the amount of carvacrol is much higher during the summer, while $p$-cymene predominates in autumn. 

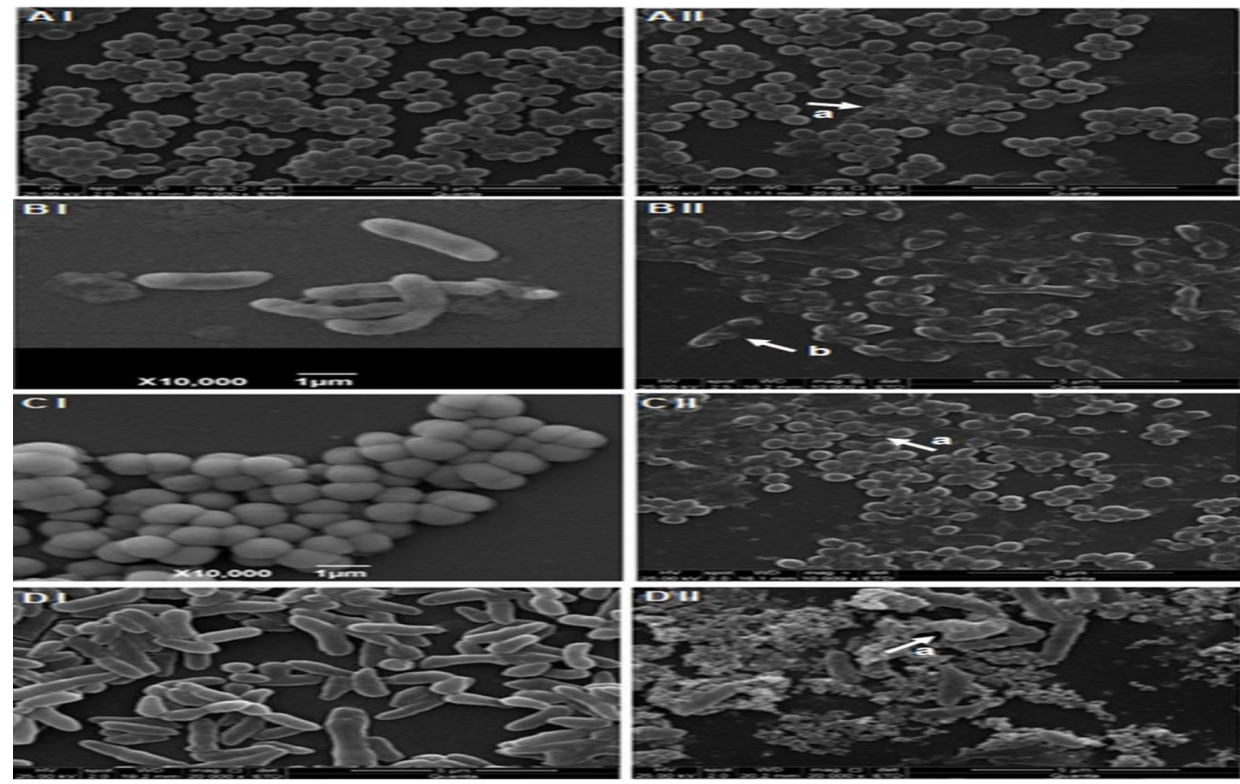

Figure 6: SEM images of bacteria. A: S. epidermidis ATCC12228. B: P. vulgaris ATCC 13315. C: M. luteus ATCC 7468. D: C. xerosis IAL 105. I: untreated bacterial cells. II: treatment with deodorant. "a": indicates deformed cells, "b": disruption of membrane integrity.

Accordingly, minor differences in the chemical composition of the essential oils can be due to physiological variation, soil types, genetic factors, vegetative stage, climate, harvest time, as well as cultivation and origin of the plants. ${ }^{32,35,36}$

Who investigated five essential oils of oregano from different regions of Europe at different times of the year. A large variation in the chemical content of those oils was found. However, there was no significant difference in the antimicrobial activity against Salmonella enterica serotype Enteritidis. On the other hand, the authors suggest that the essential oils containing carvacrol, $p$-cymene, and $\gamma$-terpinene may present a more effective antimicrobial effect.

Found carvacrol $(66.9 \mathrm{~g} / 100 \mathrm{~g})$ as being the most prevalent compound ${ }^{37}$ in the essential oil of $O$. vulgare, which also presented high content of p-cymene $(13.9 \mathrm{~g} / 100$ $\mathrm{g})$ and $\gamma$-terpinene $(7.8 \mathrm{~g} / 100 \mathrm{~g})$. The authors suggest that phenolic active compounds, such as carvacrol, sensitize the cell membrane of the bacteria by complexation to available targets (amino acids and proteins) in the cells. Thus, when saturation of such site occurs, there is gross damage and leakage of intracellular constituents.

Analyzed the chemical composition ${ }^{29}$ of the essential oil of oregano obtained from four different regions of Madeira Island, Portugal. Although the samples showed the same constituents, some quantitative differences were observed. In a region, g-terpinene was the component present in higher amount $(20.49 \%)$, whereas in others, thymol was the major component, with concentrations ranging from $30.96 \%$ to $58.0 \%$. In parallel, antimicrobial assay was performed. Among the tested microorganisms, M. luteus CCMI 322 was inhibited by all the four samples, being that two samples showed bactericidal activity (MIC $=100 \mu \mathrm{g} /$ $\mathrm{mL}$ ) and the others showed bacteriostatic activity with MIC values ranging between 100 and $200 \mu \mathrm{g} / \mathrm{mL}$.

According to the present study, the essential oil O. vulgare demonstred bactericidal activity against $P$. vulgaris ATCC (MIC $=1.4 \mathrm{mg} / \mathrm{ml})$, M. luteus ATCC (MIC=2.8 mg/ $\mathrm{mL}$ ) and $C$. xerosis IAL 105 (MIC $=1.4 \mathrm{mg} / \mathrm{mL}$ ) and bacteriostatic activity for $S$. epidermidis (MIC $=2.8 \mathrm{mg} / \mathrm{mL}$ ).

Despite the fact that the essential oil from O. vulgare obtained MIC values higher than the reference drugs, the present results are of interest due to the environmental impact and emergence of resistant bacterial strains associated with triclosan. Furthermore, the usage of antibiotics such as neomycin in deodorants is not recommended, as there are other active substances with lower toxic risks. ${ }^{38}$

Examined the antibacterial properties ${ }^{39}$ of the essential oil of oregano against $C$. xerosis, $M$. luteus and $P$. vulgaris by disk diffusion method. It was observed MIC $=1 / 50(\mathrm{v} / \mathrm{v})$ for $C$. xerosis and M. luteus and MIC $=1 / 200(\mathrm{v} / \mathrm{v})$ for $P$. vulgaris. It has been hypothesized that the activity of the oil can be attributed to the presence of carvacrol, p-cymene and $\gamma$-terpinene. 
According to oregano essential oil $^{40}$ did not show antibacterial activity against S. epidermidis A233. On the other hand, this oil was active in inhibiting $P$. vulgaris Kukem-1329 with MIC $=62.50 \mu \mathrm{g} / \mathrm{mL}$.

Unlike many antibiotics, the hydrophobic constituents present in the oils from the Origanum genus are able to gain access to the periplasm of Gram-negative bacteria through the porin proteins of the outer membrane. ${ }^{29,41}$ essential oil O. vulgare in the wall and/or in the plasma membrane of the bacteria.

Some studies employing SEM were found, showing the antibacterial effect of essential oil of $O$. vulgare against several bacteria $(S$. aureus ATCC 6538, B. subtilis ATCC 6633, E. coli ATCC 8739, S. aureus and L. monocytogenes ATCC QCF 7644). ${ }^{41-43}$ The authors observed injuries on the morphology of cell membranes. However, no studies were found demonstrating the detrimental effect of the essential oil of $O$. vulgare against the microorganisms of interest by means of SEM.

It can be observed that the deodorant containing the essential oil from oregano demonstrated bactericidal action against all bacteria tested. SEM observations confirmed the physical damage and considerable morphological alteration to the bacteria treated with the deodorant.

Dermal and ocular toxicity of oregano essential oil. ${ }^{44}$ The essential oil at 3\% did not cause skin and cutaneous irritations when administrated in wistar rats and albino rabbits and it was considered minimally toxic to the eye. In the present study, the developed deodorant contains $2 \%$ of the essential oil, percentage lower than the described study. Moreover, the addition of essential oil can improve the cosmetic properties of the final product, not only by protecting the consumer against bacterial infections, but also by contributing to the conservation of the formulation. Thus, it is also possible to reduce the usage of chemical preservatives and to formulate cosmetics with improved dermocosmetic properties. ${ }^{5,15}$

\section{CONCLUSION}

Our results support the possibility of using the essential oil from Origanum vulgare as a potential natural active antimicrobial to be applied in personal care products, such as deodorants. The usage of the essential oil from O. vulgare in deodorants as an alternative to triclosan can encourage the personal care industry to search out new raw materials for formulations and to introduce innovations in their product lines.

\section{ACKNOWLEDGEMENTS}

The authors acknowledge the financial support from CAPES and CNPq. They are also grateful to MSc Amanda Garcez and Noêmia Rodrigues for the technical assistance and Adolfo Lutz Institute Culture Collection for standard strains donation.

\section{CONFLICT OF INTEREST}

The authors declare that there is no conflict of interests

\section{REFERENCES}

1. Goossens A. Contact-allergic reactions to cosmetics. J Allergy. 2011: 1-6.

2. Witorsch RJ, Thomas JA. Personal care products and endocrine disruption: a critical review of the literature. Crit Rev Toxicol. 2010; 40(3): S1-S30.

3. Middleton JH, Salierno JD. Antibiotic resistance in triclosan tolerant fecal coliforms isolated from surface waters near waste water treatment plant outflows (Morris County, NJ, USA). Ecotoxicol Environ Saf. 2013; 88: 79-88.

4. Zarate Jr FM, Schulwitz SE, Stevens KJ, Venables BJ. Bioconcentration of triclosan, methyl-triclosan, and triclocarban in the plants and sediments of a constructed wetland. Chemosphere. 2012; 88(3): 323-29.

5. Patrone V, Campana R, Vittoria E, Baffone W. In vitro synergistic activities of essential oils and surfactants in combination with cosmetic preservatives against Pseudomonas aeruginosa and Staphylococcus aureus. Curr Microbiol. 2010; 60(4): 237-41.

6. Butler E, Whelan MJ, Ritz K, Sakrabani R, Egmond RV. The effect of triclosan on microbial community structure in three soils. Chemosphere. 2012; 89(1): 1-9.

7. Proia L, Morin S, Peipoch M, Romaní AM, Sabater S. Resistance and recovery of river biofilms receiving short pulses of Triclosan and Diuron. Sci. Total Environ. 2011; 409(17): 3129-37.

8. Tamura I, Kanbara Y, Saito M, Horimoto K, Satoh M, Yamamoto H et al. Triclosan, an antibacterial agent, increases intracellular $\mathrm{Zn}^{2+}$ concentration in rat thymocytes: Its relation to oxidative stress. Chemosphere. 2012; 86(1): 70-5.

9. Antignac E, Nohynek GJ, Re T, Clouzeau J, Toutain H. Safety of botanical ingredients in personal care products/cosmetics. Food Chem Toxicol. 2011; 49(2): 324-41.

10. Souza TM, Morais-Braga MFB, Costa JGM, Saraiva AAF, Lima MA, Coutinho HDM, Herbs in association with drugs: Enhancement of the aminoglycosideantibiotic activity by Pityrogramma calomelanos (L.) Link. J Young Pharm. 2013; 5(4): 188-90.

11. Cerqueira GS, Rocha NFM, Almeida JRGS, de Freitas APF, Lima EO, Filho JMB et al. Antimicrobial Activity of the Extract of Stem Bark of Diplotropis Ferruginea Benth. J Young Pharm. 2011; 3(4): 284-86.

12. Dayan N, Kromidas, L. "Formulating, Packaging, and Marketing of Natural Cosmetic Products", 1st ed. Wiley: New Jersey; 2011.

13. Wannes WA, Mhamdi B, Sriti J, Jemia MB, Ouchikh O, Hamdaoui G et al. Antioxidant activities of the essential oils and methanol extracts from myrtle (Myrtus communis var. italica L.) leaf, stem and flower. Food Chem Toxicol. 2010; 48(5): 1362-70.

14. Lubbe A, Verpoorte R. Cultivation of medicinal and aromatic plants for specialty industrial materials. Ind Crops Prod. 2011; 34(1): 785-801.

15. Varvaresou A, Papageorgiou S, Tsirivas E, Protopapa E, Kintziou H, Kefala V et al. Self-preserving cosmetics. Int J. Cosmet Sci. 2009. 31(3): 163-75.

16. Regnault-Roger C, Vincent C, Arnason JT. Essential Oils in Insect Control: LowRisk Products in a High-Stakes World. Annu Rev. Entomol. 2012; 57: 405-24.

17. Figuérédo G, Cabassu P, Chalcat JC, Studies of Mediterranean oregano populations. VII: chemical composition of essential oils of carvacrol-rich oregano of various origins. J. Essent. Oil Res. 2006; 18(3): 244-49.

18. Rodrigues MRA. Estudo dos óleos essenciais presentes em manjerona e orégano. Chem. M. Dissertation, Instituto de Química, Universidade Federal do Rio Grande do Sul, Porto Alegre, Brazil. 2002.

19. Souza EL, Stamford TLM, Lima EO, Trajano VN, Barbosa Filho JM. Orégano (Origanum vulgare L., Lamiaceae): uma especiaria como potencial fonte de compostos antimicrobianos. Hig. aliment. 2005; 19(132): 40-5.

20. Agiomyrgianaki A, Dais P. Simultaneous determination of phenolic compounds and triterpenic acids in oregano growing wild in Greece by ${ }^{31} \mathrm{P}$ NMR spectroscopy. 
Magn Reson Chem. 2012; 50(11): 739-48.

21. Liang $\mathrm{CH}$, Chan LP, Ding HY, So EC, Lin RJ, Wang HM et al. Free radical scavenging activity of 4-(3,4-dihydroxybenzoyloxymethyl) phenyl-o- $\beta$-Dglucopyranoside from Origanum vulgare and its protection against oxidative damage. J Agric Food Chem. 2012; 60(31): 7690-96.

22. Pelissari FM, Grossmann MV, Yamashita F, Pineda EA. Antimicrobial, mechanical, and barrier properties of cassava starch-chitosan films incorporated with oregano essential oil. J. Agric Food Chem. 2009; 57(16): 7499-504.

23. Klaschka U. Contact allergens for armpits - Allergenic fragrances specified on deodorants. Int J. Hyg Environ Health. 2012; 215(6): 584-91.

24. Lorenz C, Von Goetz N, Scheringer M, Wormuth M, Ungerbühler K. Potential exposure of German consumers to engineered nanoparticles in cosmetics and personal care products. Nanotoxicology. 2011; 5(1): 12-29.

25. ABIHPEC. [homepage on the Internet]. São Paulo: Associação Brasileira da Indústria de Higiene Pessoal, Perfumaria e Cosméticos. [cited 2013 Jul 07] Available from: http://www.abihpec.org.br, last accessed: 07/07/2013.

26. Adams RP. Identification of Essential Oil Componets by Gas Chromatography/ Mass Spectrometry. 4th ed. Allured Bussiness Media: Carol Stream Illinois; 2007.

27. Candan F, Unlu M, Tepe B, Daferera D, Polissiou M, Sökmen A et al. Antioxidant and antimicrobial activity of essential oil and methanol extracts of Achillea millefolium subsp. millefolium Afan. (Asteraceae). J Ethnopharmacol. 2003; 87(2): 215-20.

28. Gao C, Tian C, Lu Y, Xu J, Luo J, Guo X, Essential oil composition and antimicrobial activity of Sphallerocarpus gracilis seeds against selected food-related bacteria. Food Control. 2011; 22(3): 517-22.

29. Castilho PC, Feio SS, Weinhold TS, Gouveia SC. Evaluation of the antimicrobial and antioxidant activities of essential oils, extracts and their main components from oregano from Madeira Island, Portugal. Food Control. 2012; 23(2): 552-58.

30. Luz IS, Gomes Neto NJ, Tavares AG, Magnani M, Souza EL. Exposure of Listeria monocytogenes to sublethal amounts of Origanum vulgare L. essential oil or carvacrol in a food-based medium does not induce direct or cross protection. Food Res Int. 2012; 48(2): 667-72

31. Benavides S, Villalobos-Carvajal R, Reyes JE. Physical, mechanical and antibacterial properties of alginate film: Effect of the crosslinking degree and oregano essential oil concentration. J Food Eng. 2012; 110(2): 232-39.

32. Bostancioğlu RB, Kürkçüoğlu M, Başer KHC, Koparal AT. Assessment of antiangiogenic and anti-tumoral potentials of Origanum onites L. essential oil. Food Chem Toxicol. 2012; 50(6): 2002-8.

33. Busatta C, Mossi AJ, Rodrigues MRA, Cansian RL, Oliveira JV. Evaluation of Origanum vulgare essential oil as antimicrobial agent in sausage. Braz. J. Microbiol. 2007; 38(4): 610-16.

34. Tibaldi G, Fontana E, Nicola S. Growing conditions and postharvest management can affect the essential oil of Origanum vulgare L. ssp. hirtum (Link) letswaart. Ind Crops Prod. 2011; 34(3): 1516-22.

35. Khosravi AR, Shokri H, Kermani S, Dakhili M, Madani M, Parsa S. Antifungal properties of Artemisia sieberi and Origanum vulgare essential oils against Candida glabrata isolates obtained from patients with vulvovaginal candidiasis. J. Mycol Med. 2011; 21(2): 93-99.
36. Silva JPL, Duarte-Almeida JM, Perez DV, Franco BDGM. Óleo essencial de orégano: interferência da composição química na atividade frente a Salmonella Enteritidis. Cienc. tecnol. aliment. 2010; 30(1): S136-S41.

37. Azerêdo GA, Stamford TLM, Nunes PCN, Gomes-Neto NJ, Oliveira MEG, Souza EL. Combined application of essential oils from Origanum vulgare $\mathrm{L}$ and Rosmarinus officinalis L. to inhibit bacteria and autochthonous microflora associated with minimally processed vegetables. Food Res Int. 2011; 44(5) 1541-58.

38. Barata EAF. A cosmetologia: principios básicos. 1st ed., Tecnopress: São Paulo; 1995.

39. Baydar H, Sagdiç O, Ozkan G, Karadogan T. Antibacterial activity and composition of essential oils from Origanum, Thymbra and Sartureja species with commercial importance in Turkey. Food Control. 2004; 15(3): 169-72.

40. Sahin F, Güllüce M, Daferera D, Sökmen A, Sökmen M, Polissiou M et al. Biological activities of the essential oils and methanol extract of Origanum vulgare ssp. vulgare in the Eastern Anatolia region of Turkey. Food Control. 2004; 15(7): 549-57.

41. Azerêdo GA, Figueiredo RCBQ, Souza EL, Montenegro TL. Stamford changes in Listeria monocytogenes induced by Origanum vulgare L. and Rosmarinus officinalis $L$. Essential oils alone and combined at subinhibitory amounts. J. Food Saf. 2012; 32(2): 226-35.

42. Lv F, Liang H, Yuan Q, Li C. In vitro antimicrobial effects and mechanism of action of selected plant essential oil combinations against four food-related microorganisms. Food Res Int. 2011; 44(9): 3057-64.

43. Souza EL, Barros JC, Oliveira CEV, Conceição ML. Influence of Origanum vulgare L. essential oil on enterotoxin production, membrane permeability and surface characteristics of Staphylococcus aureus. Int J. Food Microbiol. 2010; 137(2) 308-11.

44. T.L. Schuch. Toxicidade dérmica e ocular do óleo essencial de orégano $3 \%$ (Origanum vulgare L.). Monograph of Faculdade de Veterinária, Universidade Federal do Rio Grande do Sul, Porto Alegre, Brazil. 2011 